\title{
Ultrasound guided supraclavicular brachial plexus block using plain ropivacaine and ropivacaine with additives
}

\author{
S Mathew ${ }^{1 *}$, S Prasad ${ }^{2}$, R Krishna ${ }^{1}$, A Kumarl, M Shiyad ${ }^{3}$ \\ Associate Professor ${ }^{1}$, Junior Resident ${ }^{2}$, Assistant Professor ${ }^{3}$ \\ Department of Anaesthesia, Kasturba Medical College, Manipal, India.
}

Context: Ultrasound (US) guided supraclavicular brachial plexus block (SBPB) provides predictable dense blockade. Inclusion of additives to local anaesthetics alters the quality of blockade.

Aim: To assess the block characteristics of ropivacaine alone and with additives in US guided SBPB.

Materials and Methods: Prospective, double blinded randomized controlled trial. Sixty patients undergoing elective upper limb surgeries under SBPB were randomly allocated to one of 3 groups: Group RR (who received $30 \mathrm{ml}$ of $0.5 \%$ ropivacaine), Group RD (30ml of $0.5 \%$ ropivacaine with $1 \mu \mathrm{g} / \mathrm{kg}$ of dexmedetomidine) and Group RM (30ml of $0.5 \%$ ropivacaine with $50 \mu \mathrm{g} / \mathrm{kg}$ of midazolam). After administration of block with above drugs, the block characteristics were assessed every $3 \mathrm{mins}$ till onset of complete blockade, every 30mins for $6 \mathrm{hrs}$, then hourly for $24 \mathrm{hrs}$. Apart from sensory and motor blockade, sedation score was also assessed.

Results: The duration of blockade (min) was significantly longer in Group RD $(907 \pm 205)$ compared to Group RR $(597 \pm 101)$ and Group RM $(605 \pm 188)$. There was no difference among the groups with respect to onset of sensory and motor blockade. The sedation scores were significantly higher in Group RD (median = 3) and Group RM (median $=2)$.

Conclusion: Addition of dexmedetomidine to ropivacaine in ultrasound guided supraclavicular brachial plexus block prolongs both sensory and motor blockade. Both dexmedetomidine and midazolam when added to ropivacaine produce significant sedation.

Keywords: Ropivacaine; dexmedetomidine; midazolam; brachial plexus; ultrasound

\section{Introduction}

Use of regional anaesthesia has waxed and waned over the past decades. Twenty first century saw its resurgence with availability of improved technology and equipment for reliable administration. Improved perioperative outcomes coupled with increased patient satisfaction, as well as minimal alteration in homeostasis are some of the reasons for the growing popularity of this field. ${ }^{1}$

\section{*Correspondence: S Mathew \\ E mail: shajimanipal@yahoo.co.in \\ iD https://orcid.org/0000-0001-8992-8339}

Received: $28 / 06 / 2017$

Accepted: 20/10/2017

DOI: http://doi.org/10.4038/slja.v26i1.8261

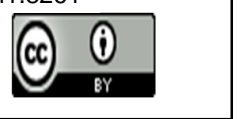

Inclusion of additives (opioids or non-opioids) with local anaesthetics in brachial plexus block is aimed at quicker onset, enhanced quality and duration of blockade. Popular additives being used are clonidine, dexmedetomidine, buprenorphine, morphine, fentanyl and midazolam. ${ }^{2}$ The search for an ideal additive has been an elusive journey for researchers. This led us to the conduct of this study to contribute to the available data on additives. The additives used in our study were dexmedetomidine and midazolam.

\section{$\underline{\text { Aim }}$}

To assess the block characteristics of ropivacaine alone and ropivacaine with additives in ultrasound guided supraclavicular brachial plexus blockade.

Objectives

Primary objective was to compare the duration of analgesia, sensory and motor blockade. 
Secondary objective was to compare the onset of sensori-motor blockade, sedation score, complications and side effects.

\section{Material and methods}

This randomized, prospective double blinded study was commenced after obtaining institutional ethics committee approval. Sixty patients undergoing elective upper limb surgeries under SBPB were enrolled for the study. They were randomly allocated to one of three groups using a computer-generated randomization table. Written informed consent was obtained from all patients.

Patients aged between 18 - 60yrs of either gender, weighing $>50 \mathrm{~kg}$, belonging to ASA-PS I and II, and scheduled for elective upper limb orthopaedic procedures under SBPB were included in the study. Patients who refused to participate, pregnant patients, patients on anticoagulants, those with known local anaesthetic allergy and those who didn't fulfil inclusion criteria were excluded.

Observer 1, anaesthesiology resident who performed the preoperative evaluation, confirmed that the patients met the inclusion criteria, obtained a written informed consent and recorded observations during and after the procedure. Observer 2 was the anaesthesiology consultant who is experienced in providing USG peripheral nerve blocks and administered brachial plexus blockade for all the patients. Observer 3 was the trained nursing staff in the postoperative unit, who assessed the sensory block, motor block and sedation score as instructed by the resident, after the patient was transferred to postoperative ward. Observer 1 and 3 were blinded to the group allocation and the study drugs used. All patients were kept fasting as per standard guidelines and aspiration prophylaxis administered. Anxiolytic premedication was avoided due to the possible interference with assessment of sedation. Group $\mathrm{RR}$ received $30 \mathrm{ml}$ of $0.5 \%$ ropivacaine with $1 \mathrm{ml}$ of $0.9 \%$ saline. Group RD received $30 \mathrm{ml}$ of $0.5 \%$ ropivacaine with $1 \mu \mathrm{g} / \mathrm{kg}$ of dexmedetomidine in $1 \mathrm{ml}$ of $0.9 \%$ saline. Group RM received $30 \mathrm{ml}$ of $0.5 \%$ ropivacaine with $50 \mu \mathrm{g} / \mathrm{kg}$ of midazolam in $1 \mathrm{ml}$ of $0.9 \%$ saline.

On the day of surgery, standard monitors as per ASA guidelines were connected and an intravenous (IV) cannula secured in the non- operative limb once the patient arrived in the premedication room. Patient was positioned supine with head turned away from the limb to be operated. The injection site was cleansed with povidone iodine and covered with sterile drapes. A high frequency adult linear ultrasound probe covered with sterile tegaderm was then placed over the supraclavicular region. Sterile water based gel was used as acoustic couplant between probe and skin. The brachial plexus was identified in relation to the pulsating subclavian artery and the hyperechoic first rib. Local anaesthesia at the injection site was provided with $2 \mathrm{ml} 2 \%$ plain lignocaine. The plexus was then approached using an in-plane (IP) technique with a $5 \mathrm{~cm}$ sterile nerve stimulating needle. Once the needle tip reached the nerve sheath and following negative aspiration for blood/air, $31 \mathrm{ml}$ of the study drug was injected around the plexus under vision at the two locations mentioned in Figure 1, in boluses of $5 \mathrm{ml}$ with repeated aspirations in between. (Position 1: angle between subclavian artery and first rib. Position 2: outside the nerve sheath).

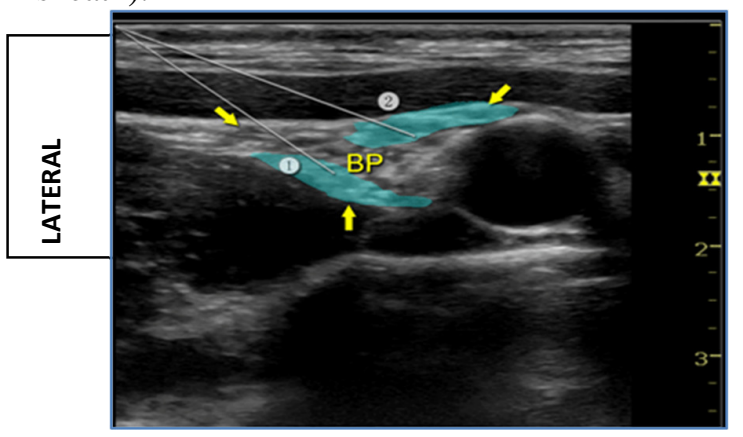

Figure 1: Ultrasound image of brachial plexus block showing the needle positions

In patients with sparing at site of tourniquet application, block was supplemented with intercostobrachial block with $5 \mathrm{ml}$ of $0.25 \%$ bupivacaine using $24 \mathrm{G}$ hypodermic needle.

The onset of sensory blockade was defined as the time interval between injection of local anaesthetic and loss of prick sensation in radial, median and ulnar dermatomes on the ipsilateral upper limb. This was assessed by checking for prick sensation every $3 \mathrm{~min}$ till the onset of loss of sensation, then every 30min up to first 6hrs after the administration of block and hourly up to 24hrs from time of complete block onset. During the first 6 hrs after administration of block, the surgeon was requested to check for sensory blockade in the distribution of ulnar, radial and 
median nerves, if the surgery is ongoing, since the sterility of surgical field had to be maintained. Sensory block was graded into three. ${ }^{3}$ Grade 0 : Sharp prick felt. Grade 1: Analgesia, dull sensation felt. Grade 2: Anaesthesia, no sensation felt.

The sensory block was assessed on the palmar surface of index finger, palmar surface of little finger and dorsum of thumb for median, ulnar and radial nerve respectively. ${ }^{4}$

The onset of motor blockade was defined as the time interval from administration of the drug to loss of movements of ipsilateral upper limb. This was assessed every $3 \mathrm{~min}$ till loss of finger movements, then every 30min for first $6 \mathrm{hrs}$ and then hourly till finger movements regained. Motor block was graded using modified Bromage scale for upper extremities. ${ }^{3}$ Grade 0: Normal motor function. Grade 1: Ability to move only fingers. Grade 2: Complete motor block with inability to move below wrist and fingers. Sedation was assessed using sedation score described by Culebras et al. ${ }^{5}$ Score 1: Awake and alert. Score 2: Sedated, responding to verbal stimulus. Score 3: Sedated, responding to mild physical stimulus. Score 4: Sedated, responding to moderate or severe physical stimulus. Score 5: Not arousable. Duration of sensory block was defined as time interval between loss of prick sensations to its reappearance. Duration of motor block was defined as time interval between loss of movements of ipsilateral upper limb to reappearance of the movements. Time to rescue analgesia was defined as the time interval from injection of study drug to first request for analgesia by patient once block has worn off.

An unsuccessful block was defined as absence of grade 1 sensory or motor block till 30min after injection of drug. In such a circumstance of inadequate or patchy block, it was to be supplemented with general anaesthesia. Also, if the duration of surgery were to be unduly prolonged and the effect of the block were to wear off, rescue analgesia was to be given in the form of intravenous fentanyl $1 \mu \mathrm{g} / \mathrm{kg}$ and infusion of propofol $50-100 \mu \mathrm{g} / \mathrm{kg} / \mathrm{min}$.

\section{Statistical analysis}

The sample size was calculated based on a pilot study in which 5 patients were enrolled in each group randomly. The results showed mean $( \pm$ standard deviation) duration of sensory blockade in group RR, RD and RM as $474 \pm 90.99$ mins,
$743 \pm 153.52 \mathrm{mins}$ and $558 \pm 126.57 \mathrm{mins}$ respectively. Similarly, the mean $( \pm$ standard deviation) duration of motor blockade was found to be $456 \pm 53.66 \mathrm{mins}, 702 \pm 158.18 \mathrm{mins}$ and 504 $\pm 131.45 \mathrm{mins}$ in group $\mathrm{RR}, \mathrm{RD}$ and $\mathrm{RM}$ respectively.

Considering a $30 \%$ difference in the duration of blockade as significant, the following formula was used for sample size calculation from the above data.

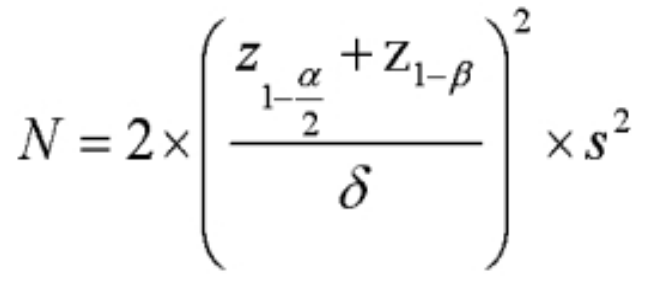

$\mathrm{N}=$ size per group

$\mathrm{Z}_{\mathrm{x}}=$ standard normal deviate for a one or two-

sided $\mathrm{x}$

$\delta=$ real difference between two treatment effect

$\mathrm{s}^{2}=$ Polled standard deviation of both

comparison groups

$\alpha=0.05$

Power $(1-\beta)=0.8$

The formula was applied for both duration of sensory and motor blockade. After comparing all three groups for both the parameters, it was found that a minimum of 16 patients were required in each group for a power of study of $80 \%$ at $95 \%$ confidence interval. Twenty patients were included in each group to account for drop outs, thus amounting to a total study population of sixty patients. The data obtained from the study was analysed using one-way ANOVA, Kruskal Wallis test and Chi-square test. For all the tests in the study, $\mathrm{P}<0.05$ was considered significant and $\mathrm{P}<0.001$ was considered highly significant. SPSS version 16.0 software was used to analyse the data.

\section{Results}

Demographic data (age, weight and gender) and the ASA PS of patients in all the three groups were comparable. (Table 1) Also the mean ( \pm standard deviation) duration of surgery was similar in all the groups. (Table 2) The onset of both sensory and motor block was found to be comparable in all three groups. (Table 3) The duration of sensory blockade in Group RD was significantly longer than Group RR and Group RM. (Table 4) Similarly, the duration of motor blockade in Group RD was 
prolonged compared to Group RR and Group RM. (Table 4). A similar pattern was observed when the time to rescue analgesia was compared between the three groups. (Table 4) It was observed that patients in Group RD had higher sedation scores at one hour compared to Group RR and Group RM. (Table 5) The requirement of intercostobrachial block was found to be higher in Group RM and RR as compared to Group RD. (Table 6) All patients were haemodynamically stable during and after injection of study drug and none of the patients were noticed to have any neurological deficits on postoperative follow up.

Table 1: Patient characteristics

\begin{tabular}{|l|l|l|l|l|}
\hline $\begin{array}{l}\text { Patient } \\
\text { characteristics }\end{array}$ & $\begin{array}{l}\text { Group } \\
\mathrm{RR} \\
(\mathrm{n}=20)\end{array}$ & $\begin{array}{l}\text { Group } \\
\mathrm{RD} \\
(\mathrm{n}=20)\end{array}$ & $\begin{array}{l}\text { Group } \\
\mathrm{RM} \\
(\mathrm{n}=20)\end{array}$ & P value \\
\hline $\begin{array}{l}\text { Age in years } \\
\text { (mean } \pm \text { SD) }\end{array}$ & $\begin{array}{l}38.45 \pm \\
13.06\end{array}$ & $\begin{array}{l}36.10 \pm \\
11.71\end{array}$ & $\begin{array}{l}40.40 \pm \\
11.04\end{array}$ & $0.53^{*}$ \\
\hline $\begin{array}{l}\text { Weight in } \\
\text { kilograms } \\
\text { (mean } \pm \text { SD) }\end{array}$ & $\begin{array}{l}63.70 \pm \\
9.61\end{array}$ & $\begin{array}{l}68.35 \pm \\
11.70\end{array}$ & $\begin{array}{l}60.95 \pm \\
9.75\end{array}$ & $0.08^{*}$ \\
\hline $\begin{array}{l}\text { Gender } \\
\text { (Male/Female) }\end{array}$ & $13 / 7$ & $17 / 3$ & $14 / 6$ & $0.33^{* *}$ \\
\hline ASA-PS & $14 / 6$ & $17 / 3$ & $17 / 3$ & $0.39^{* *}$ \\
(I/II) & & & & \\
\hline
\end{tabular}

* One-way ANOVA

$\mathrm{P}<0.05$ : Statistically significant

${ }^{* *}$ Chi-square test

Table 2: Duration of surgery

\begin{tabular}{|l|l|l|l|l|}
\hline Duration & $\begin{array}{l}\text { Group } \\
\text { RR } \\
(\mathrm{n}=20)\end{array}$ & $\begin{array}{l}\text { Group } \\
\text { RD } \\
(\mathrm{n}=20)\end{array}$ & $\begin{array}{l}\text { Group RM } \\
(\mathrm{n}=20)\end{array}$ & P value \\
\hline $\begin{array}{l}\text { Duration of } \\
\text { surgery } \\
\text { (min) }\end{array}$ & $\begin{array}{l}71.4 \pm \\
28.8\end{array}$ & $\begin{array}{l}70.8 \pm \\
25.2\end{array}$ & $75 \pm 48$ & $0.9^{*}$ \\
\hline
\end{tabular}

* One-way ANOVAP < 0.05: Statistically significant
Table 3: Onset of blockade

\begin{tabular}{|l|l|l|l|l|}
\hline $\begin{array}{l}\text { Onset of } \\
\text { block }\end{array}$ & $\begin{array}{l}\text { Group } \\
\text { RR } \\
(\mathrm{n}=20)\end{array}$ & $\begin{array}{l}\text { Group } \\
\text { RD } \\
(\mathrm{n}=20)\end{array}$ & $\begin{array}{l}\text { Group RM } \\
(\mathrm{n}=20)\end{array}$ & P value \\
\hline $\begin{array}{l}\text { Sensory } \\
\text { onset } \\
\text { (min) } \\
\text { (mean } \pm \text { SD) }\end{array}$ & $\begin{array}{l}17.70 \pm \\
8.47\end{array}$ & $\begin{array}{l}22.05 \pm \\
12.06\end{array}$ & $\begin{array}{l}17.75 \pm \\
7.5\end{array}$ & $0.26^{*}$ \\
\hline $\begin{array}{l}\text { Motor onset } \\
\text { (min) } \\
\text { (mean } \pm \text { SD) }\end{array}$ & $\begin{array}{l}19.55 \pm \\
7.67\end{array}$ & $\begin{array}{l}24.55 \pm \\
13.36\end{array}$ & $20 \pm 7.68$ & $0.22^{*}$ \\
\hline
\end{tabular}

* One-way ANOVA

$\mathrm{P}<0.05$ : Statistically significant

Table 4: Duration of blockade and analgesia

\begin{tabular}{|l|l|l|l|l|}
\hline $\begin{array}{l}\text { Duration of } \\
\text { block/ rescue } \\
\text { analgesia }\end{array}$ & $\begin{array}{l}\text { Group RR } \\
(\mathrm{n}=20)\end{array}$ & $\begin{array}{l}\text { Group RD } \\
(\mathrm{n}=20)\end{array}$ & $\begin{array}{l}\text { Group RM } \\
(\mathrm{n}=20)\end{array}$ & $\begin{array}{l}\mathrm{P} \\
\text { valu } \\
\mathrm{e}\end{array}$ \\
\hline $\begin{array}{l}\text { Sensory } \\
\text { blockade }\end{array}$ & $\begin{array}{l}546 \pm \\
\text { (min) }\end{array}$ & $\begin{array}{l}859 \pm \\
213.75\end{array}$ & $\begin{array}{l}570 \pm \\
181.05\end{array}$ & $\begin{array}{l}<.00 \\
1 *\end{array}$ \\
(mean \pm SD) & & & & \\
\hline $\begin{array}{l}\text { Motor } \\
\text { blockade }\end{array}$ & $492 \pm$ & $816 \pm$ & $507 \pm$ & $\begin{array}{l}<.00 \\
\text { (min) }\end{array}$ \\
(mean \pm SD) & 94.57 & 207.30 & 170.24 & $1 *$ \\
\hline $\begin{array}{l}\text { Time to } \\
\text { rescue } \\
\text { analgesia }\end{array}$ & $597.20 \pm$ & $906.80 \pm$ & $605.40 \pm$ & 0.00 \\
(min) & 100.88 & 240.96 & 188.35 & $1 *$ \\
(mean \pm SD) & & & & \\
\hline
\end{tabular}

*One-way ANOVA

$\mathrm{P}<0.001$ : Statistically highly significant

Post-hoc test: Tukey's test results for duration of sensory blockade

Group RR and RD were statistically different (P $<0.001)$

Group RD and RM were statistically different (P $<0.001)$

Group RR and RM were comparable in terms of duration of block $(\mathrm{P}=0.89)$

\section{Post-hoc test: Tukey's test results for} duration of motor blockade

- Group RR and RD were statistically different (P $<0.001)$

- Group RD and RM were statistically different (P $<0.001)$ 
- Group RR and RM were comparable in terms of duration of block $(\mathrm{P}=0.899)$

\section{Post-hoc test: Tukey's test results for time to rescue analgesia}

- Group RR and RD were statistically different (P $<0.001)$

- Group RD and RM were statistically different (P $<0.001)$

- Group RR and RM were comparable in terms of duration of block $(\mathrm{P}=0.899)$

Table 5: Sedation score

\begin{tabular}{|l|l|l|l|l|}
\hline Sedation score & $\begin{array}{l}\text { Group } \\
\text { RR }\end{array}$ & $\begin{array}{l}\text { Group } \\
\text { RD }\end{array}$ & $\begin{array}{l}\text { Group } \\
\text { RM }\end{array}$ & $\begin{array}{l}\text { P } \\
\text { value }\end{array}$ \\
\hline $\begin{array}{l}\text { Sedation score at one } \\
\text { hour } \\
\text { (Median score) }\end{array}$ & 1 & 3 & 2 & $<$ \\
$(1-2)$ & $(2-4)$ & $(1-3)$ & $0.001^{\#}$ \\
\hline
\end{tabular}

\# Kruskal Wallis test

$\mathrm{P}<0.001$ : Statistically highly significant

Table 6: Requirement of intercostobrachial nerve block

\begin{tabular}{|l|l|l|l|l|}
\hline $\begin{array}{l}\text { Intercostobra } \\
\text { chial nerve } \\
\text { block }\end{array}$ & $\begin{array}{l}\text { Group } \\
\mathrm{RR} \\
(\mathrm{n}=20)\end{array}$ & $\begin{array}{l}\text { Group } \\
\mathrm{RD} \\
(\mathrm{n}=20)\end{array}$ & $\begin{array}{l}\text { Group } \\
\mathrm{RM} \\
(\mathrm{n}=20)\end{array}$ & P value \\
\hline $\begin{array}{l}\text { Needed } / \text { Not } \\
\text { needed }\end{array}$ & $2 / 18$ & $0 / 20$ & $5 / 15$ & $0.046^{* *}$ \\
\hline
\end{tabular}

** Chi-square test $\quad \mathrm{P}<0.05$ : Statistically

significant

\section{Discussion}

The benefit of regional anaesthesia over general anaesthesia has been well recognised especially with respect to minimal anaesthetic exposure, reduced need of systemic analgesics and early discharge. Regional anaesthesia has its own problems like patchy nerve block, early wearing off, local anaesthetic toxicity, anxiety and requirement of intraoperative sedation. If these problems can be overcome, regional anaesthesia will be a safe and comfortable experience for most patients. Thus, anaesthesiologists started probing into new avenues searching for answers. Although intravenous benzodiazepines, barbiturates or opioids seemed to be the most obvious answer, the haemodynamic effects produced by these drugs could not be overlooked. With the advent of $\alpha_{2}$ agonists like clonidine and dexmedetomidine, intravenous sedation gained importance again as they were found to produce sedation without significant respiratory compromise. These goals gave birth to the concept of additives along with local anaesthetics in regional anaesthesia. The aim was to produce quick, dense and prolonged block as well as reduce the requirement of systemic analgesics and anxiolytics. But these too are not without side effects. Significant bradycardia, hypotension and even cardiac arrest have been reported with these agents at therapeutic doses. ${ }^{6}$

The present study was aimed at comparing the block characteristics of ropivacaine with and without additives in ultrasound guided SBPB. The additives used were dexmedetomidine and midazolam. All the patients in our study were provided US guided SBPB by same observer (observer 2) in order to avoid any interpersonal variation in the method of administration.

Regarding the duration of block, our results are similar to those obtained in previous studies using dexmedetomidine as additive. The prospective, double-blinded, controlled volunteer study conducted by Marhofer et al using dexmedetomidine $(20 \mu \mathrm{g})$ as additive with $(0.75 \%)$ ropivacaine in ultrasound guided ulnar nerve block revealed, $60 \%$ prolongation of sensory and motor block with perineural dexmedetomidine ${ }^{7}$ Kathuria et al in their study obtained similar results with $50 \mu \mathrm{g}$ dexmedetomidine in $30 \mathrm{ml}$ of $0.5 \%$ ropivacaine for SBPB. $^{8}$ Swami et al concluded that dexmedetomidine $(1 \mu \mathrm{g} / \mathrm{kg})$ when added to local anaesthetic (bupivacaine 0.25\%) in SBPB increased the duration of sensory and motor block and also the duration of analgesia. ${ }^{3}$ Similar prolongation of duration of block was also observed by Esmaoglu et al in their study to evaluate the effect of dexmedetomidine $(100 \mu \mathrm{g})$ as additive to levobupivacaine $(40 \mathrm{ml}$ of $0.5 \%$ levobupivacaine) in axillary brachial plexus block. ${ }^{9}$ Zhang et al also recorded prolonged sensory and motor blockade duration in patients who received $50 \mu \mathrm{g}$ dexmedetomidine in $40 \mathrm{ml}$ of $0.33 \%$ ropivacaine when compared to control group for axillary brachial plexus blockade. ${ }^{10}$ Rutkowska $\mathrm{K}$ et al observed that systemic dexmedetomidine prolongs the duration of brachial plexus block in patients with end-stage renal failure scheduled for creation of arteriovenous fistula. ${ }^{11}$ In our study, the duration of block in Group RM was comparable with Group RR, without any clinically or statistically significant difference. These results using midazolam as additive in nerve block are different from those obtained from previous studies. Jarbo et al noticed that duration of sensory block was prolonged when midazolam 
was used as an additive with $0.5 \%$ bupivacaine in SBPB when compared to $0.5 \%$ bupivacaine alone. $^{12}$ There was no difference in the duration of motor blockade between the groups. However, Shaikh et al obtained slightly different results with midazolam. ${ }^{13}$ The duration of motor block was found to be significantly longer when midazolam was used as additive with bupivacaine, while duration of sensory block was comparable in both groups.

Our results with respect to onset of block were different from the previous studies using same additives. Esmaoglu et al noticed that the onset of sensory and motor block was shorter in the group with dexmedetomidine as additive. ${ }^{9}$ This difference could be due to use of a higher dose of dexmedetomidine $(100 \mu \mathrm{g})$ irrespective of body weight. Similar results were also obtained by Marhofer et al with perineural dexmedetomidine and Kaygusuzet al with dexmedetomidine in axillary brachial plexus block. ${ }^{7,14}$ However Das et al noticed that when dexmedetomidine was added to $0.5 \%$ ropivacaine in supraclavicular brachial plexus block, there was no clinically significant difference in the onset of block. ${ }^{15}$ Similarly Rancourt et al evaluated the effect of dexmedetomidine $(1 \mu \mathrm{g} / \mathrm{kg})$ when added to $10 \mathrm{ml}$ of $0.5 \%$ ropivacaine for posterior tibial nerve block. They recorded similar onset of sensory blockade in the dexmedetomidine group ${ }^{16}$

Jarbo et al noted that patients who received a combination of midazolam and bupivacaine in the nerve block had faster onset of sensory and motor blockade. ${ }^{12}$ This was hypothesised to be due to the local anaesthetic properties of midazolam. Laiq et al in their study using bupivacaine in combination with midazolam concluded similar results. ${ }^{17}$ However our results failed to show any significant difference in the onset of both sensory and motor block similar to those obtained by Shaikh et al. ${ }^{14}$

Similarly, Trivedi et al used clonidine or midazolam for SBPB with bupivacainelignocaine combination. The two groups showed no clinically significant difference in onset and duration of motor and sensory blockade. ${ }^{18}$

Sedation after provision of block was assessed using the sedation score described by Culebras et al. ${ }^{5}$ The results of our study were similar to those obtained by Agarwal $S$ et al where dexmedetomidine was added to bupivacaine and sedation was assessed using modified Ramsay sedation score. ${ }^{19}$ They observed that patients who received dexmedetomidine had higher sedation scores. Jarbo et al also observed that use of midazolam as additive in brachial plexus block produced higher sedation scores compared to the control group. ${ }^{12}$

Though bradycardia with use of dexmedetomidine was observed by Esmaoglu et al in 7 out of 30 patients studied, no such events occurred during our study probably due to the lower doses used. ${ }^{9}$

Inclusion of additives in nerve blocks is a common practice. However which additive to be used is a dilemma considering the wide array of drugs available now. An additive which produces dense and prolonged blockade along with adequate sedation helps in avoiding use of additional analgesics or sedatives. According to various studies as well as our observations in this study, dexmedetomidine may be considered an ideal drug among various additives when used in appropriate doses.

\section{Conclusions}

Based on this study, we would like to conclude that inclusion of dexmedetomidine with ropivacaine in ultrasound guided supraclavicular brachial plexus block prolongs both sensory and motor blockade. Also, addition of dexmedetomidine or midazolam to ropivacaine produces significant sedation.

\section{ANZCTR TRIAL NUMBER: ACTRN 12614001151628}

\section{References}

1. Griffin J, Nicholls B. Ultrasound in regional anaesthesia. Anaesthesia 2010;1:1-12. https://doi.org/10.1111/j.13652044.2009.06200.x PMid:20377542

2. Murphy DB, McCartney CJ, Chan VW. Novel analgesic additives for brachial plexus block: a systematic review. AnesthAnalg2000;90:1122-8. https://doi.org/10.1097/00000539-200005000$\underline{00023}$

PMid:10781465

3. Swami SS, Keniya VM, Ladi SD, Rao R. Comparison of dexmedetomidine and clonidine ( $\alpha 2$ agonist drugs) as an adjuvant to local anaesthesia in supraclavicular brachial plexus block: A randomised double-blind prospective study. Indian J Anaesth2012;56:243-9. https://doi.org/10.4103/0019-5049.98767 PMid:22923822 PMCid:PMC3425283 
4. Ravi NA, Ritesh MK, Parmila SJ, Dipsheekha C. Role of midazolam as an additive to local anesthetic in supraclavicular brachial plexus block. Asian J Med Res 2012;1:103-7.

5. Culebras X, Van Gessel E, Hoffmeyer P, Gamulin Z. Clonidine combined with a long acting local anaesthetic does not prolong postoperative analgesia after brachial plexus block but does induce hemodynamic changes. AnesthAnalg. 2001;92:199-204.

https://doi.org/10.1097/00000539-200101000$\underline{00038}$

PMid:11133627

6. Afonso J, Reis F. Dexmedetomidine: current role in anesthesia and intensive care. Rev Bras Anestesiol.2012;62:118-133. https://doi.org/10.1016/S0034-7094(12)70110-1

7. Marhofer D, Knetter SC, Marhofer P, et al. Dexmedetomidine as an additive to ropivacaine prolongs peripheral nerve block: a volunteer study. $\quad \mathrm{Br}$ J Anaesth. 2013;110:438-42. https://doi.org/10.1093/bja/aes400 PMid:23161360

8. Kathuria S, Gupta S, Dhawan. Dexmedetomidine as an adjuvant to ropivacaine in supraclavicular brachial plexus block. Saudi J Anaesth. 2015;9:148-54.

https://doi.org/10.4103/1658-354X.152841

PMid:25829902 PMCid:PMC4374219

9. Esmaoglu A, Yegenoglu F, Akin A, Turk CY. Dexmedetomidine added to levobupivacaine prolongs axillary brachial plexus block. AnesthAnalg2010;111:1548-51. https://doi.org/10.1213/ANE.0b013e3181fa3095 PMid:20889939

10. Zhang Y, Wang CS, Shi JH, et al. Perineural administration of dexmedetomidine in combination with ropivacaine prolongs axillary brachial plexus block. Int $\mathrm{J}$ ClinExp Med 2014;7:680-5.

PMid:24753763 PMCid:PMC3992408

11. Rutkowska K, Knapik P, Misiolek H. The effect of dexmedetomidine sedation on brachial plexus block in patients with end-stage renal disease. Eur JAnaesthesiol2009;26:851-5. https://doi.org/10.1097/EJA.0b013e32832a2244 PMid:19550340

12. Jarbo K, Batra YK, Panda NB. Brachial plexus block with midazolam and bupivacaine improves analgesia. Can J Anesth 2005;52: 822-6. https://doi.org/10.1007/BF03021776 PMid:16189333

13. Shaikh SI, Veena K. Midazolam as an additive in supraclavicular brachial plexus block. Anaesth pain and intensive care 2012;16:7-12.

14. Kaygusuz K, Kol I O, Duger C, et al. Effects of adding dexmedetomidine to levobupivacaine in axillary brachial plexus block. Current therapeutic research2012;73:103-11. https://doi.org/10.1016/j.curtheres.2012.03.001 PMid:24648597 PMCid:PMC3954022

15. Das A, Majumdar S, Halder S, et al. Effect of dexmedetomidine as adjuvant in ropivacaineinduced supraclavicular brachial plexus block: A prospective, double-blinded and randomized controlled study. Saudi J Anaesth 2014;8:72-7. https://doi.org/10.4103/1658-354X.144082 PMid:25538527 PMCid:PMC4268534

16. Rancourt MP, Albert NT, Côté M, et al. Posterior tibial nerve sensory blockade duration prolonged by adding dexmedetomidine to ropivacaine. AnesthAnalg.2012;115:958-62. https://doi.org/10.1213/ANE.0b013e318265bab7 PMid:22826530

17. Laiq N, Khan MN, Arif M, Khan S. Midazolam with bupivacaine for improving analgesia quality in brachial plexus block for upper limb surgeries. J Coll Physicians Surg Pak. 2008;18:674-8. PMid:18983789

18. Trivedi V, Patel N. A comparative clinical study of injection clonidine versus midazolam in supraclavicular brachial plexus block for sedation and postoperative analgesia. J Indian Med Assoc. 2010;108:563-7. PMid:21510527

19. Agarwal S, Aggarwal R, Gupta P. Dexmedetomidine prolongs the effect of bupivacaine in supraclavicular brachial plexus block. J AnaesthesiolClinPharmacol 2014;30:3640.

https://doi.org/10.4103/0970-9185.125701 PMid:24574591 PMCid:PMC3927290 